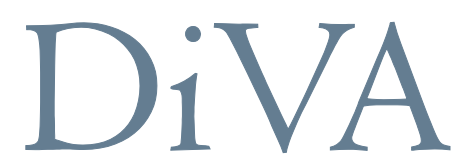

http://uu.diva-portal.org

This is an author produced version of a paper published in Lethaia (Blackwell Publishing). This paper has been peer-reviewed but does not include the final publisher proof-corrections or journal pagination.

Citation for the published paper:

Popov, Leonid E.; Bassett, Michael G.; Holmer, Lars E.; Skovsted, Christian B.; Zuykov, Michael A.

"Earliest ontogeny of Early Palaeozoic Craniiformea: implications for brachiopod phylogeny"

Lethaia, 2010, Vol. 43, Issue 3, pp. 323-333

URL: http://dx.doi.org/10.1111/j.1502-3931.2009.00197.x

The definitive version is available at http://wileyonlinelibrary.com. Access to the definitive version may require subscription. 


\title{
Earliest ontogeny of Early Palaeozoic Craniiformea: implications for brachiopod phylogeny
}

\author{
LEONID E. POPOV, MICHAEL G. BASSETT, LARS E. HOLMER, CHRISTIAN B. \\ SKOVSTED \& MICHAEL ZUYKOV
}

Leonid E. Popov, Michael G. Bassett, Lars E. Holmer, Christian B. Skovsted \& Michael Zuykov. 2009 \#\# \#\#: Earliest ontogeny of Early Palaeozoic Craniiformea: implications for brachiopod phylogeny. Lethaia, Vol. \#\#, pp. \#\#\#-\#\#\#.

Well preserved specimens of the Early Palaeozoic craniiform brachiopods Orthisocrania and Craniops retain clear evidence of a lecithotrophic larval stage, indicating the loss of planktotrophy early in their phylogeny. The size of the earliest mineralised dorsal shell was less than $100 \mu \mathrm{m}$ across, and the well preserved shell structure in these fossil craniiforms allows their earliest ontogeny to be compared directly with that of living Novocrania, in which the first mineralised dorsal shell (metamorphic shell) is secreted only after settlement of the lecithotrophic larvae. Immediately outside this earliest shell (early post-metamorphic or brephic shell) and in the rest of the dorsal valve the primary layer in both fossil and living craniiforms has characteristic radially arranged laths, which are invariably lacking in the earliest dorsal shell. The ventral valve of the fossil specimens commonly preserves traces of an early attachment scar (cicatrix), which is equal in size to the dorsal metamorphic shell, and the brephic post-metamorphic ventral valve also has a primary shell with radially arranged laths. However, a primary shell with radial laths is completely lacking in the ventral valve of living Novocrania, indicating that heterochrony may have been involved in the origin of the encrusting mode of life in living craniids; the entire ventral valve of Recent craniids (with the possible exception of Neoancistrocrania) may correspond to the earliest 
attachment scar of some fossil taxa such as Orthisocrania. It is also probable that the unique absence of an inner mantle lobe as well as the absence of lobate cells in Novocrania could be the result of heterochronic changes. The dorsal valve of both fossil and living craniiforms has a marked outer growth ring, around $500 \mu \mathrm{m}$ across, marking the transition to the adult, and a significant change in regime of shell secretion. The earliest craniiform attachment is considered to be homologous to the unique attachment structures described recently in polytoechioids (e.g. Antigonambonites) and other members of the strophomenate clade. However, unlike the craniiforms, polytoechioids and strophomenates all have planktotrophic larvae, and planktotrophy is most probably a plesiomorphic character for all Brachiopoda. $\square$ Ontogeny, Phylogeny, Early Palaeozoic, Brachiopoda, Craniiformea.

Leonid E.Popov, Michael G. Bassett [leonid.popov@museumwales.ac.uk; mike.bassett@ museumwales.ac.uk], Department of Geology, National Museum of Wales, Cathays Park, Cardiff CF10 3NP, Wales, UK; Lars E. Holmer, Christian B. Skovsted [Lars.Holmer@pal.uu.se; Christian.Skovsted@geo.uu.se],Department of Earth Sciences, Palaeobiology, Uppsala University, SE-752 36 Uppsala, Sweden; and Michael Zuykov [m.zuykov@mail.ru], G. Khlopin Radium Institute 28, 2-nd Murinskiy ave., St.Petersburg, 194021, Russia; manuscript received \#\#, revised \#\#\#\#.

Key words: Brachiopoda, Craniiformea, ontogeny, phylogeny, Early Palaeozoic.

THE PHYLOGENETIC origins and relationships of the subphylum Craniiformea within the Phylum Brachiopoda have been a matter of some conflicting debate mostly reflecting uncertainty as to their earliest divergence from stem group ancestors (e.g. Carlson 1995; Holmer et al. 1995; Popov et al. 1993, 1996; Williams et al. 1996; Cohen \& Weydmann 2005). In part, this may be due also 
to limited understanding of the detailed early life history of fossil and extant craniiforms - a subject that has been studied in only a few recent publications (Nielsen 1991; Freeman \& Lundelius 1999; Freeman 2000, 2001; Luter 2007).

The recognition that extant Novocrania is characterised by having a lecithotrophic larval stage is well established (Nielsen 1991 and references therein), and with few exceptions it has been assumed that this was also a characteristic feature of all fossil craniiforms (e.g. Holmer et al. 1995; Williams et al. 1996). Freeman \& Lundelius (1999) published the only detailed study into the earliest ontogeny of Early Palaeozoic Craniiformea and concluded that they all showed evidence of a planktotrophic life history, with preserved larval shell.

Here we demonstrate that lecithotrophy evolved early in craniiform phylogeny, as evidenced in Early Palaeozoic taxa. The attachment of the earliest craniiform larva also shows strong similarities with the enigmatic attachment structures of strophomenate brachiopods, which are clearly not homologous with the pedicle of extant Rhynchonelliformea (Popov et al. 2007), and in a wider perspective this type of attachment may also be homologous with the umbonal perforation and colleplax of the Chileata (Holmer et al. 2009). However, unlike the craniiforms, all strophomenates and chileates have planktotrophic larvae, and planktotrophy is most probably plesiomorphic for all Brachiopoda and other Cambrian metazoans (e.g. Freeman \& Lundelius 2005; Raff 2008).

\section{Materials and methods}

All brachiopod specimens used in this study were isolated and picked from residues after washing and sieving soft clay in water; no chemicals were used in the process. The majority of the craniide and craniopside shells have been affected to a varying degree by secondary alteration because of neomorphism of high-magnesium calcite during early diagenesis (for details see Williams \& Cusack in Williams et al. 2007), whereas shells of strophomenides and orthides from the same 
localities have a well preserved original shell structure, including the microgranular primary shell layer of Bassettorthis (Bassett et al. 2008b, Fig. 2; Zuykov \& Butts 2008, Figs 2.20, 21). However, the altered remnants of a primary layer with characteristic radially aligned laths expressed on the surface (e.g. see Williams \& Cusack in Williams et al. 2007) is well preserved in our studied craniide and craniopside specimens (e.g. Fig. 1).

For detailed examination of shell fabrics, specimens were cleaned ultrasonically and subsequently etched in 2\% EDTA for 5-15 minutes. After coating with gold palladium they were studied under a scanning electron microscope using a Cam Scan MaXim 2040S SEM with variable vacuum chamber.

The following brachiopods were studied: Orthisocrania curvicostae (Huene, 1899), from the Upper Ordovician, Sandbian, Gryazno Formation, Klyasino Quarry, western St Petersburg region, Russia (locality K-2 of Zuykov in Zuykov \& Butts 2008). Novocrania anomala (Müller, 1776), Recent, Gullmaren Fjord, west coast of Sweden. Craniops implicata (Sowerby, 1839) from the Silurian, Wenlock, Mulde Formation of Fröjel, Gotland, Sweden.

Figured specimens are housed in the National Museum of Wales (NMW) and Naturhistoriska Riksmuseet, Stockholm (RM).

\section{Terminology}

The first and earliest identifiable stage in the ontogeny of the brachiopod shell is the protegulum, which Williams et al. (1997) defined this term as the 'first-formed shell of periostracum and mineralised lining secreted simultaneously by both mantles'. However, subsequent studies indicate that this definition is now somewhat misleading, because it has been reported that the protegulum in some brachiopods was not secreted by both mantles simultaneously and may not be mineralised (Popov et al. 2007, 2009; Holmer et al. 2009). 
Freeman \& Lundelius (2005, p. 221) discriminated between an embryonic and a larval protegulum. The latter, in application to the craniiform and rhynchonelliform brachiopods, was applied to the shell formed by the end of metamorphosis and usually defined by a halo. Therefore to avoid further confusion here it is termed as the metamorphic shell, since it is exhibits peripheral growth during metamorphosis in both fossil and living craniiforms (Nielsen 1991; Popov et al. 2007). This corresponds to first formed shell as used by Popov et al. (2007; see also Williams 2003), but as noted by these authors it is not equivalent to the protegulum as defined by Williams et al. (1997). It is likely that the metamorphic shell in craniiforms is defined by the dorsal halo, and it was not secreted simultaneously over the whole surface by the outer mantle epithelium.

The next preserved stage in the ontogeny is usually termed the brephic shell, and this stage has been interpreted somewhat differently in various publications. It was broadly defined by Williams et al. (1997, p. H425) as 'juvenile stage in shell development following secretion of protegulum..., it can be distinguished from protegulum by presence of growth lines and from neanic shells by absence of radial ornament'. In that broad definition the term was applied recently to the description of the ontogeny of siphonotretides (Popov et al. 2009) and the enigmatic brachiopod Salanygolina (Holmer et al. 2009). However, this definition lacks precision because it may include also the shell that is formed after secretion of the protegulum, but before termination of metamorphosis, so can be applied therefore both to the metamorphic and early postmetamorphic stages of shell growth, which may also include larval shell formed during the free swimming stage of planktotrophic larvae.

Freeman \& Lundelius (2005) restricted the term brephic shell to the growth stage after metamorphosis was completed, and that practice is followed here. Thus, the brephic shell of craniiforms was characterised by the formation of a cicatrix attachment by the surface of the ventral valve and it shows direct evidence of accretionary growth, which was controlled by the 
adult mantle. This includes the formation of a primary layer with radially arranged laths. It is distinguished from the remainder of the adult shell by a distinctive change in shell secretion and the onset of adult ornamentation.

How to recognise lecithotrophy versus planktotrophy in extinct craniiforms? Chuang (1977) postulated that the embryonic, larval and post-metamorphic shells in Recent organophosphatic linguliform brachiopods can be delineated clearly by simply studying the pattern of discontinuities (termed halo by Chuang 1977) in shell growth visible on the shell surface, and commonly also by the different surface textures of the larval and post-metamorphic shell. This approach was adopted subsequently in studies into the early ontogeny of well preserved fossil linguliform brachiopods (e.g. Holmer 1989; Williams 2003). Subsequently, studies were also expanded to fossil calcareous-shelled brachiopods (Freeman \& Lundelius 1999, 2005; Popov et al. 2007; Bassett et al. 2008a, b), and Freeman \& Lundelius (1999) published a pioneering study of Early Palaeozoic Craniiformea. By studying the pattern of surface discontinuities, the latter authors concluded that the transition from planktotrophy to lecithotrophy in craniide larvae had not occurred earlier than the Jurassic.

More recent studies have pointed to the problems of directly applying Chuang's (1977) method of interpreting surface discontinuities in ontogenetic studies of fossil craniiforms and rhynchonelliforms. Popov et al. (2007) stressed that calcareous-shelled brachiopods are subject to a completely different set of taphonomic pathways by comparison with the organophosphaticshelled linguliforms, because their valves consist of high magnesium calcite. This mineral is somewhat unstable and has a tendency towards re-crystallisation, resulting in a significant alteration of the original shell matrix, which is sometimes confusing structurally and can be mistakenly interpreted as the result of biogenic shell secretion and resorption (Cusack \& Williams in Williams et al. 2007; Popov et al. 2007). Moreover, calcareous-shelled brachiopods have a 
different succession of changes in shell secretion associated with initial attachment and the relative timing of secretion of dorsal and ventral valves (e.g. Williams et al. 1997), and proving or disproving the existence of an organic embryonic shell or protegulum in extinct craniiforms is difficult even in otherwise perfectly preserved specimens (Popov et al. 2007).

The end of metamorphosis in rhynchonelliforms and craniiforms coincides with the first differentiation of adult mantles and appearance of adult mantle setae (which are absent in extant craniiforms; Williams et al. 2007). Popov et al. (2007) showed that these changes cannot be interpreted by simply investigating the surface pattern of growth discontinuities, but they must also be traced through detailed studies of changes in the shell microstructure, including ornament and arrangement of secondary shell structural elements, such as fibres and bladed or tabular laminae.

As noted by Williams \& Cusack (in Williams et al. 2007, p. 2486), it is possible to observe the primary shell layer in some fossil craniides, which as in extant Novocrania comprises a succession of laminar sheets. This pattern is expressed on the external surface as radially arranged laths (Figs 1B, D, G, H), which can be recognised even in specimens that have gone through partial re-crystallisation of the shell. In particular, the laths are well preserved both in Orthisocrania (Figs 2E-G) and craniopsides (Fig. 3C, D) and can be used for discrimination of inner boundaries of the post-metamorphic shell, signifying the first evidence of accretionary growth. Williams \& Cusack (in Williams et al. 2007, Fig, 1571a, c) also showed that the dorsal valve in Recent Novocrania has a distinct halo, forming around the first metamorphic shell, which is about $240 \mu \mathrm{m}$ wide and develops up until the fourth day after settlement. No distinct protegulum can be observed within the metamorphic shell.

\section{Early ontogeny of Early Palaeozoic Craniiformea}

\section{Orthisocrania}


The umbonal region of well preserved adult dorsal valves of Orthisocrania curvicostae has a smooth circular area, about $260 \mu \mathrm{m}$ across and defined by a distinct halo, which is here considered to form the outer boundary of the metamorphic shell. The early post-metamorphic (brephic) shell is defined by a strong growth ring, about $750-800 \mu$ m wide; fine, distinctive growth marks are developed here, as well as radially arranged laths, but the brephic shell lacks the strongly developed, raised radial ornamentation of adult shells (Fig. 1G). The adult shell is marked by the appearance of the strongly raised radial ornament (Fig. 1E, F, H).

The diameter of the metamorphic shell corresponds closely to the size of the attachment scar in the umbonal area of the ventral valve. In one specimen the shape of the attachment scar indicates that the larva first settled on a loose cylindrical bioclast, which then appears to have shifted position, causing a shift in the pattern of shell secretion, which again indicates the onset of accretionary shell growth (Fig. 2D). The attachment scar has a central flattened circular area, about $240-260 \mu \mathrm{m}$ across, which probably gives an approximate indication of the shell size at the time of the first mineralised ventral valve secretion. This area definitely exceeds the size of a true protegulum, and it is somewhat larger than the metamorphic shell in Novocrania as developed three days after settlement ( 190 $\mu$ m across; Nielsen 1991, fig. 15c). An even smaller circular area, about $80 \mu \mathrm{m}$ in diameter, may well represent the initial attachment scar of the Orthisocrania larva (Fig. 2H). It is comparable in size with the dorsal protegulum of extant Novocrania formed shortly after settlement (Nielsen 1991)

The surface microstructure of the secondary shell within the attachment scar does not show any distinct adult tabular lamination, which is evident outside the outer boundary of the scar. This may suggest that the secretion of the secondary shell in Orthisocrania was suppressed during formation of the attachment scar. Alternatively, in the initial growth stages the ventral valve might have been entirely organic in composition. 
All characters of early shell growth in Novocrania and Orthisocrania are remarkably similar in size and shell structure and all evidence points to the lecithotrophic nature of the Orthisocrania larva. In contrast to the analysis of Freeman \& Lundelius (1999), this suggests that formation of the outer growth ring in the juvenile post-metamorphic (brephic) shell of Orthisocrania coincides with a significant change in regime of shell secretion in the ventral valve, but not with a transition from a pelagic to sessile mode of life.

\section{Craniops}

In the dorsal valve of Craniops implicata, the earliest preserved stage in ontogeny is represented by an almost circular area $85-90 \mu \mathrm{m}$ in diameter (Fig. 3H). This area is evenly convex and smooth, without any folding and ornamentation and is bounded by a distinct halo; this is interpreted here as representing the metamorphic shell. The surrounding post-metamorphic (brephic) shell is about 550-600 $\mu \mathrm{m}$ across, defined by the first strong growth lamella. The surface of the metamorphic shell has a pattern of fine, radially arranged laths, which suggests the onset of the adult shell secretion, with differentiated primary and secondary layers.

Similarly, the ventral umbo has a circular area about 90-95 $\mu$ m wide, with a depressed central zone bounded by an elevated rim; this zone most probably corresponds with the earliest attachment area of the larva (Fig. 3A-C, F). The ventral post-metamorphic shell coincides with the area of the cicatrix, which is about $550 \mu \mathrm{m}$ wide, defined by an outer initial strong growth lamella. The cicatrix is usually flattened or gently concave and in some specimens has an uneven surface and growth disturbances, reflecting an uneven surface of the substrate (Fig. 3G). It also has the distinct, radially arranged lath pattern characteristic of the adult shell.

An identical pattern of ontogeny can be observed on the conjoined valves of Craniops sp. (erroneously named Pholidops) described by Freeman and Lundelius (1999, fig. 3G, H). They interpreted the circular area in the ventral valve, about $130 \mu \mathrm{m}$ in diameter, as a rudiment of the 
embryonic shell, but we consider it to represent the primary attachment scar formed shortly after settlement, when differentiation of the ventral larval mantle was already completed. It is about the same size as the 'protegulum' in the dorsal valve shown by Freeman and Lundelius (1999, fig. $3 \mathrm{H})$, but this is most probably not the embryonic shell, but was formed after settlement because it corresponds closely with the area of cicatrix attachment in the ventral valve.

Thus there is no evidence that the ontogeny of Craniops included a prolonged free swimming stage as suggested by Freeman and Lundelius (1999), because the region of the craniopside shell between the halo and the first strong growth lamella already shows differentiation into primary and secondary layers, and the cicatrix attachment structure reflects the surface of the substrate. It is also evident that the shell outside the halo is post-metamorphic and that dorsal valve within the halo corresponds to the metamorphic shell. The absence of deformation and lobation on the surface of the metamorphic shell may suggest that it was at least partly mineralised, unlike the larval shells of paterinides (Williams et al. 1998) and the first formed shells of polytoechioids and other strophomenates (Popov et al. 2007).

The precise interpretation of the ventral metamorphic shell is more speculative. It was most probably secreted by the larva when it was attached to the substrate, which may suggest a delay in ventral mantle differentiation as seen in Recent craniides. However, there is virtually no variation in size and shape of the metamorphic shell within the studied ventral valves, and it is comparable in size to the dorsal metamorphic protegulum (Figs 3A, C, F, H). Thus it is possible that both valves were secreted almost simultaneously, late in metamorphosis, and the size of the metamorphic shell of Craniops is well within the range of the brachiopod egg size of extant Novocrania, which has a lecithotrophic larva. The initial secretion of the shell occurred after settlement, when the animal became attached by the ventral side of the body, but unlike in Recent craniides the ventral valve was secreted almost simultaneously or shortly after the formation of the 
dorsal metamorphic protegulum. Given these factors, the larva of Craniops was most probably lecithotrophic and the protegulum formed after settlement.

\section{Early ontogeny of Recent Novocrania}

The embryology of Recent craniides has been described by Nielsen (1991) for Novocrania, and early post-larval stages are known from the description by Rowell (1960). The cleavage of the eggs of Novocrania is holoblastic and radial. The gastrula is formed by invagination of the thickened side of the blastula. Nielsen $(1991,2005)$ suggested that the mesoderm in Novocrania formed from the posteroventral part of the archenteron through modified enterocoely. However, Freeman (2000) demonstrated, through observations on regional specification during embryogenesis, that the mesoderm is formed through multipolar cell ingression from the archenteron. Lüter (in Williams et al. 2007, p. 2344-2347) suggested (based on an unpublished ultrastructural study by Grobe 1999) that there is a continuous mesodermal layer, which to some extent is compressed by setal sacs, and that a separation of coelomic compartments does not take place throughout early larval development of Novocrania. Coelomic separation into two pairs of compartments then occurs shortly before settlement and they still stay in contact. Thus, the supposed trimeric body plan cannot be confirmed for larvae in any groups of brachiopods (for further discussion see Lüter in Williams et al. 2007, p.2350).

At a somewhat later stage the blastopore is closed on the posterior end of the larva. A fullgrown larva is characterised by three pairs of dorsal setal bundles. The larva of Novocrania is lecithotrophic and has a very short free-swimming stage. In a short time before settlement, the larval body becomes strongly curved ventrally by the contraction of the lateroventral longitudinal muscles extending from the anterior pair of coelomic pouches along the underside of the endoderm to the posterior end of the larva. It settles on the fourth day after fertilisation and is 
attached by the posterior part of the body, with the attachment area situated dorsally to the position of the closed blastopore (Nielsen 1991, 2005).

Both valves are secreted after settlement, with a significant delay in the secretion of the ventral valve. There is a circular glandular area about $50 \mu \mathrm{m}$ in diameter on the dorsal side of a full-grown free-swimming larva. On settlement, the dorsal protegulum is about $70-80 \mu \mathrm{m}$ in diameter. There is no ventral protegulum. Nielsen (1991) briefly stated that the ventral valve was secreted from a single epithelial area situated on the dorsal side of the larva, but there is no detailed documentation or illustration in support of this suggestion and it well may be an observational artefact, as discussed further below.

The differentiation of the lophophore and internal organs (such as a nervous system, nephridia and gonads) are still unknown for craniids, but it is clear that the lophophore is also formed after settlement (Nielsen 1991).

A median tentacle is present at the growth stage with 3 pairs of lophophore tentacles, but it is lost before the time when the lophophore has acquired 6 pairs of tentacles (Rowell 1960; Chuang 1974). The presence of a median tentacle in the lophophore of juvenile Novocrania was questioned by Lüter (in Williams et al. 2007) based on the observations of Nielsen (1991); however, this is difficult to understand since Nielsen (1991, p. 23) clearly stated that he did not study the differentiation of the lophophore in Novocrania.

An open mouth is first identifiable at the stage with three pairs of lophophore tentacles (Rowell 1960; Nielsen 1991). According to Rowell (1960) the intestine ends blindly before the animal has acquired 5 or 6 pairs of cirri.

\section{Discussion and phylogenetic implications}

Recent studies of strophomenate brachiopods (Popov et al. 2007; Bassett et al. 2008a, b), siphonotretides (Popov et al. 2009) and the enigmatic chileid-like Salanygolina (Holmer et al. 
2009) suggest that both the pattern of ontogenetic succession and probably the larval body plan of the craniiforms can be found outside of the Subphylum Craniiformea. Although all these Early Palaeozoic brachiopods differ from craniides and craniopsides in having a planktotrophic larva, they have a remarkably similar pattern of metamorphosis, which occurs after settlement. It includes the following characteristic traits: (1) the early loss of larval attachment on the posterior part of the body, which is (2) replaced at the end of metamorphosis by a unique type of attachment that forms from structures secreted by the ventral mantle, as well as (3) a significant delay in the ventral mantle differentiation and secretion of the ventral valve. In addition, all these groups had two pairs of setal sacs identical to those of the newly settled larva of Novocrania; therefore this feature was probably inherited from a free swimming stage.

In particular, the ontogeny described from the strophomenate (billingsellide) Antigonambonites is closest to that of Early Palaeozoic craniiforms, since it also lacks evidence for a juvenile pedicle attachment (Popov et al. 2007). In contrast, the ventral brephic shell of Salanygolina has a posterior flange, which may suggest that the earliest attachment was by a posterior pedicle that later atrophied and was replaced by an attachment structure that emerged through the umbonal perforation (Holmer et al. 2009). This type of change in attachment has been described also from the Upper Cambrian siphonotretide Siphonobolus (Popov et al. 2009), but in Siphonobolus, the larval pedicle was replaced early in metamorphosis with an attachment by the modified ventral mantle, emerging through the umbonal perforation, whereas in Salanygolina this replacement probably took place at the end of metamorphosis (Holmer et al. 2009).

Although the craniiforms lack a true trimeric larva, adult Novocrania can be regarded as a 'functionally trimeric' animal; their hydrostatic coelom is subdivided into the following three compartments, each controlled by muscles: (1) the great brachial canal; (2) body cavity; and (3) a small, undivided coelomic cavity (so-called 'Analkammer' after Blochmann 1892) in the posterior end of the body. Nielsen (2005, p. 427) refers to this morphological feature as '... the small fourth 
pair of coeloms observed lateral to the rectum' in Novocrania. As pointed out by Starobogatov (1979), this terminal posterior part of the body may be homologous to the pedicle lobe of the rhynchonelliform larva, which long ago lost its primary function for attachment after settlement. Thus, it is also possible that the larva of Salanygolina and the siphonotretides had a pedicle lobe, containing a coelomic cavity, which was homologous to the pedicle lobe of rhynchonelliform larvae and used for larval attachment on settlement.

Similarities in the ontogeny of craniides, craniopsides, strophomenates, siphonotretides, and chileid-like forms like Salanygolina indicate that the general characters of ontogeny and probably the general body plan of the larva observed in extant craniides were established already by the early Cambrian. However, most evidence currently points to the fact that planktotrophy is plesiomorphic for all Brachiopoda and other Cambrian metazoans (e.g. Freeman \& Lundelius 2005; Raff 2008), and the lecithotrophic larvae of craniides and craniopsides are probably apomorphic; further derived characters also include the lack of a differentiated larval pedicle lobe, which is shared with the strophomenates. Thus, the interpretation by Carlson (in Williams et al. 2007, p. 2899) that the absence of a pedicle constitutes a primitive state in craniiforms and rhynchonelliforms is highly unlikely.

Williams et al. (1998) described the larva of the Paterinida, a group which also shares many characteristic traits with the craniiforms, strophomenates, and Salanygolina: e.g. the planktotrophic larva of the paterinides also had two pairs of larval setal sacs, and the brephic shell shows a large posteromedian gap between the valves, which could only have accommodated a pedicle rudiment. However, in all known derived paterinides, the earliest pedicle was functional throughout ontogeny, as shown by attached specimens from the Burgess Shale (e.g. Briggs et al. 1994). Thus it is possible that the adult pedicle in paterinides was homologous to the larval pedicle of Salanygolina and siphonotretides, as well as to the posterior part of the larval pedicle lobe and the adult pedicle of rhynchonellate brachiopods. 
It is not immediately clear why the paterinide type of pedicle would have been lost secondarily in craniiforms and strophomenates, but the following two scenarios can be proposed, which do not necessarily exclude one another: (1) Popov et al. (1993) and Holmer et al. (1995) pointed to the fact that rhynchonelliform and craniiform brachiopods lack dermal muscles $-\mathrm{a}$ feature that tends to substantially weaken the robustness of the body wall. Late Cambrian strophomenates (billingsellides) and Ordovician craniiforms (e.g., craniides and trimerellides) were most abundant in the shallow tropical shelves of Gondwana and Laurentia - environments that would have been affected by seasonal storm activities (Bassett et al. 2002), and therefore they may have been under strong selective pressure to adopt an encrusting or ambitopic life strategy as adults. This may have resulted in an early reduction of the larval pedicle, to be replaced progressively earlier in ontogeny by an encrusting mode of attachment, or finalising in an ambitopic mode of life, which is evident in Early Palaeozoic craniiforms and strophomenates. (2) An alternative pathway was that a pedicle attachment was retained from earlier types of attachments inherited from stem group brachiopods, such as the sessile tube-dwelling Eccentrotheca (Skovsted et al. 2008), the more brachiopod-like Micrina (Holmer et al. 2008), Paterimitra (Skovsted et al. 2009), and the even more enigmatic Anomalocalyx (Brock 1999).

Zhang et al. (2007) described the first possible Kutorgina with preserved soft tissue from the Early Cambrian Chengjiang fauna. It is relevant to note that Kutorgina has a strong, well preserved pedicle emerging between the valves. Silicified specimens of Early Cambrian Kutorgina from other areas have a pseudodeltidium and a small umbonal ventral foramen, which was generally considered as a pedicle opening (e.g. Popov et al. 1997), but unfortunately these characters are not seen clearly in the specimens from Chengjiang. If the ventral umbonal foramen and pseudodeltidium of kutorginides and chileides are indeed homologous, the most probable explanation is that the adult pedicle in kutorginides was derived from the larval pedicle lobe, possibly through hypermorphosis, while the ventral umbonal foramen represented the atrophied 
rudiment of the ancestral adult attachment structure. Thus the pedicles of kutorginides and rhynchonellates may possibly be homologous, and it may well be that the pedicle attachment in kutorginides and the later rhynchonellates evolved via the acquisition of a connective or cartilagelike tissue in the larval pedicle (Popov in Williams 2007, p. 2848). This may then have resulted in the degeneration of the coelomic space in the pedicle, which was replaced gradually by a new and more robust supporting structure. It is more probable, however, that kutorginides retained a rudimentary coelomic space in the pedicle and posterodorsally located anus (Rowell and Caruso 1985; Zhang et al. 2007) and therefore show transitional morphology between the chiliates and rhynchonellates.

Both Early Palaeozoic and Recent craniiforms completely lack any preserved traces of a ventral valve forming prior to settlement, with secretion of the ventral valve occurring only after attachment to the substratum. The dorsal larval shell of Antigonambonites does not show any trace of a median mound, but a median mound is present in the strophomenide Leptaena (Bassett et al., 2008a, fig. 1L, P. S) suggesting that at least in some early strophomenates a dorsal protegulum was already secreted sometime during the free swimming stage of development. However, all such structures are lacking in the ventral valve of strophomenates and Salanygolina. By contrast, Late Cambrian siphonotretides have minute dorsal and ventral valves about 50-60 $\mu \mathrm{m}$ across, which may well represent a protegulum that formed already by the end of the embryonic stage (Popov et al. 2009), and the growth of the earliest siphonotretide dorsal valve shows distinct similarities with Early to Mid Cambrian paterinides described by Williams et al. (1998). By contrast, in paterinides, the bivalved larval shell was probably formed prior to settlement and both valves underwent continuous peripheral growth. Therefore, the delayed formation of the ventral valve as typified in the Early Palaeozoic craniiforms and strophomenates can be interpreted most probably as an apomorphic state. 


\section{Conclusions}

(1) Lecithotrophy is an apomorphic character found in all examined Early Palaeozoic Craniiformea.

(2) Planktotrophy is plesiomorphic for all Brachiopoda.

(3) The early attachment of the craniiform larva is very similar and probably homologous to the attachment structures of strophomenate brachiopods, as well as to the ventral umbonal foramen and colleplax of chileides, Salanygolina, and siphonotretides.

(4) The attachment mechanism of the craniiform larva is not homologous to the pedicle attachment of extant Rhynchonelliformea.

Acknowledgements. - Leonid Popov and Michael Bassett acknowledge logistical and financial support from the National Museum of Wales. The work of Lars Holmer and Cristian Skovsted was supported by grants from the Swedish Natural Sciences Research Council (VR). Michael Zuykov acknowledges collaborative assistance during his study visits to Cardiff.

\section{References}

Bassett, M.G., Popov, L.E. \& Egerquist, E. 2008a: Pedicle preservation in a Silurian rhynchonelliformean brachiopod from Herefordshire, England: soft-tissue or an artefact of interpretation? Earth and Environmental Science Transactions of the Royal Society of Edinburgh 98 (for 2007), 303-308.

Bassett, M.G., Popov, L.E. \& Egerquist, E. 2008b: Early ontogeny of some Ordovician-Silurian strophomenate brachiopods: significance for interpreting evolutionary relationships within early Rhynchonelliformea. Fossils and Strata 54, 13-20. 
Bassett, M.G., Popov, L.E. \& Holmer, L.E. 2002: Brachiopods: Cambrian - Tremadoc precursors to Ordovician radiation events. In Crame, J.A. and Owen, A.W. (eds): Palaeobiogeography and biodiversity change: a comparison of the Ordovician and Mesozoic-Cenozoic radiations, 13-23. Geological Society, London.

Blochmann, F. 1892: Untersuchungen über den bau der Brachiopoden. 1. Die Anatomie von Crania anomala, O.F. Muller, 65 pp. Verlag Von Gustav Fischer, Jena.

Briggs, D.E.G., Erwin, D.H. \& Collier, F.J. 1994: The Fossils of the Burgess Shale, 238 pp. Smithsonian Institution Press, Washington.

Brock, G.A. 1999: An unusual micromorphic brachiopod from the Middle Cambrian of northeastern New South Wales, Australia. Records of the Australian Museum 51, 179-186.

Carlson, S.J. 1995: Phylogenetic relationships among extant brachiopods. Cladistics 11, 131-197. Chuang S.H. 1974: Observations on the ciliary feeding mechanisms of the brachiopod Crania anomala. Journal of the Zoological Society of London 173, 441-449.

Chuang, S.H. 1977: Larval development in Discinisca (inarticulate brachiopod). American Zoologist 17, 39-54.

Cohen, B.L. \& Weydmann, A. 2005: Molecular evidence that phoronids are a subtaxon of brachiopods (Brachiopoda: Phoronata) and that genetic divergence of metazoan phyla began long before the Early Cambrian. Organisms, Diversity \& Evolution 5, 253-273. (doi:10.1016/j.ode.2004.12.002)

Freeman, G. 2000: Regional specificiation during embryogenesis in the craniiform brachiopod Crania anomala. Developmental Biology 227, 219-238.

Freeman, G. 2001: The developmental biology of brachiopods. In S. J. Carlson \& M. R. Sandy, eds., Brachiopods Ancient and Modern: A Tribute to G. Arthur Cooper. The Paleontological Society Papers 7, 69-88. 
Freeman, G. \& Lundelius, J.W. 1999: Changes in the timing of mantle formation and larval life history traits in linguliform and craniiform brachiopods. Lethaia 32, 197-217.

Freeman, G. \& Lundelius, J.W. 2005: The transition from planktotrophy to lecithotrophy in larvae of Lower Palaeozoic Rhynchonelliform brachiopods. Lethaia 38, 219-54.

Gorjansky, V.Iu., \& Popov, L.Ye. 1985: Morfologiya, sistematicheskoe polozhenie i proiskhozhdenia bezzamkovykh brakhiopod s karbonatnoj rakovinoj [The morphology, systematic position, and origin of inarticulate brachiopods with carbonate shells]. Paleontologicheskii Zhurnal 1985, 3-13. (In Russian)

Gorjansky, V.Iu., \& Popov, L.Ye. 1986: On the origin and systematic position of the calcareousshelled inarticulate brachiopods. Lethaia 19, 233-240.

Grobe, P. 1999: Zur Entwicklung und Ultrastruktur der Larvae von Neocrania anomala (Müller, 1776), 37 pp. Diplom-Thesis, University of Göttingen. Göttingen.

Huene, F. 1899: Zur Systematik der Craniaden. Neuen Jahrbuch fur Mineralogie, Geologie und Paleontologie, Bd. 1 (1899), 138-151, 12 pl.

Holmer, L.E. 1989: Middle Ordovician phosphatic inarticulate brachiopods from Västergötland and Dalarna, Sweden. Fossils and Strata 26, 172 p.

Holmer, L.E., Popov, L.E., Bassett, M.G \& Laurie, J. 1995: Phylogenetic analysis and classification of the Brachiopoda. Palaeontology 38, 713-741.

Holmer, L. E., Skovsted, C. B., Brock, G. A., Valentine, J.L. and Paterson, J. R. 2008. The Early Cambrian tommotiid Micrina, a sessile bivalved stem group brachiopod. Biological letters 4 (2008), 724-728.

Holmer, L.E., Pettersson Stolk, S. Skovsted, C.B., Balthasar, U. \& Popov, L.E. 2009: The enigmatic Early Cambrian Salanygolina - a stem group of rhynchonelliform chileate brachiopods? Palaeontology 52, 1-10. 
Lüter, C. 2007: Recent brachiopods collected during the deep-sea cruise SO 168 ZEALANDIA with the research vessel FS Sonne between Mt. Spong (Tasman Sea) and the Chatham Islands (Pacific) in 2002-2003. In Harper, D.A.T. Long, S.L. \& Nielsen, C. (eds): Proceedings of the $5^{\text {th }}$ International Brachiopod Congress, Copenhagen, July 4-8, 2005. Blackwell. London. Fossils and Strata 54.

Müller, O.F. 1776: Zoologiae Danicae Prodromus, seu Animalium Daniae et Norvegiae indigenarum characteres, nomina, et synonyma imprimis popularium, xxxii +282 pp. Typis Hallageriis, Havniae [Copenhagen].

Nielsen, C. 1991: The development of the brachiopod Crania (Neocrania) anomala (O.F. Müller) and its phylogenetic significance. Acta Zoologica 72, 7-28.

Nielsen, C. 2005: Trochophora larvae: cell-lineages, ciliary bands and body regions. 2. Other groups and general discussion. Journal of Experimental Zoology 304B, 401-447.

Popov, L.E., Bassett, M.G., Holmer, L.E. \& Laurie, J. 1993: Phylogenetic analysis of higher taxa of Brachiopoda. Lethaia 26, 1-5.

Popov, L.E., Bassett, M.G., Holmer, L.E. \& Ghobadi Pour, M., 2009: Early ontogeny and soft tissue preservation in siphonotretide brachiopods: New data from the Cambrian-Ordovician of Iran. Gondwana Research (Online only). doi:10.1016/j.gr.2009.01.009.

Popov, L.E., Holmer, L.E. \& Bassett, M.G. 1996: Radiation of the earliest calcareous brachiopods. In Copper, P. \& Jin, J. (eds): Brachiopods, Proceedings of the Third International Brachiopod Congress Sudbury, Ontario, Canada, 2-5 September 1995, 209-213. A.A. Balkema. Rotterdam, Brookfield.

Popov, L.E., Egerquist, E. \& Holmer, L.E. 2007: Earliest ontogeny of Middle Ordovician rhynchonelliform brachiopods (Clitambonitoidea and Polytoechioidea): implications for brachiopod phylogeny. Lethaia 40, 85-96. 
Popov, L.E., Holmer, L.E., Rowell, A.J. \& Peel, J.S. 1997: Early Cambrian brachiopods from North Greenland. Palaeontology 40, 337-354.

Raff, R.A. 2008: Origins of the other metazoan body plans: the evolution of larval forms. Proceedings of the Royal Society B 363, 1473-1479. (doi:10.1098/rstb.2007.2237)

Rowell, A.J. 1960: Some early stages in the development of the brachiopod Crania anomala (O. F. Müller). Annals and Magazine of Natural History (series 13) 3, 35-52.

Rowell, A.J. 1965: Inarticulata. H359-H361. In MOORE, R.C., (ed.): Treatise on Invertebrate Paleontology. Part H, Brachiopoda, xxxii + 927 pp. The Geological Society of America, New York, and the University of Kansas Press, Lawrence.

Rowell, A.J., \& Caruso, N.E. 1985: The evolutionary significance of Nisusia sulcata, an early articulate brachiopod. Journal of Paleontology 59, 1227-1242.

Skovsted, C.B., Brock, G.A., Paterson, J.R., Holmer, L.E. \& Budd, G.E. 2008: The scleritome of Eccentrotheca from the Lower Cambrian of South Australia: lophophorate affinities and implications for tommotiid phylogeny. Geology 36, 171-174. (doi: 10.1130/G24385A.1)

Skovsted, C.B., Holmer, L.E., Larsson, C.M, Högström, A.E.S., Brock, G.A., Topper, T.P., Balthasar, U., Petterson Stolk, S. \& Paterson, J.R. 2009: The scleritome of Paterimitra: an early Cambrian stem group brachiopod from South Australia. Proceedings of the Royal Society B (Online only). (doi:10.1098/rspb.2008.1655)

Sowerby, J.D.C. 1839: Shells. 589-712. In Murchison, R.I. The Silurian System, 768 pp., pls 1-37. John Murray, London.

Starobogatov, Ya.,I. 1979: Evolution of the pelagic larvae of Protostomia and problem of the main body components. Zoological Journal 78, 149-160. (In Russian).

Williams, A. 2003: Microscopic imprints on the juvenile shells of Palaeozoic linguliform brachiopods. Palaeontology 46, 67-92. 
Williams, A., Carlson, S.J., Brunton, C.H.C., Holmer, L.E. \& Popov, L.E. 1996: A supra-ordinal classification of the Brachiopoda. Philosophical Transactions of the Royal Society of London (B) $351,1171-1193$.

Williams, A., James, M.A., Emig, C.C., Mackay, S. \& Rhodes, M. 1997: Anatomy, 7-188. In Kaesler, R. (ed.): Treatise on invertebrate paleontology. Part H Brachiopoda (Revised) 1. Geological Society of America and University of Kansas Press, Boulder, Colorado and Lawrence, Kansas.

Williams, A., Popov, L.E., Holmer, L.E. \& Cusack, M. 1998: The diversity and phylogeny of the paterinate brachiopods. Palaeontology 41, 221-262.

Williams A. James, M.A., Bruton, C.H.C., Carlson, S.J., Alvares, F., Baker, P.G., Bassett, M.G., Boucot, A. J., Carter, J.L., Cocks, L.R.M., Cohen, B.L., Curry, G.B., Cusack, M., Emig, Gourvennec, R., Harper, D., Holmer, L.E., Lee, D.E., Logan, A., Lüter, C., C.C., MacKinnon, D.I., Mancenido, M.O., Mergl, M., Popov, L.E., Racheboeuf, P.R., Rubel, M., Savage, N.M., Smirnova, T.N., Sun, D., \& Wright, A.D. 2007: Treatise on Invertebrate Paleontology, Part H (Brachiopoda), Part H, Brachiopoda (revised), 6: Suppliment. Geological Society of America and University of Kansas, i-l+22321-3226.

Zhang, Z., Robson, S.P., Emig, C.C. \& Shu, D. 2008: Early Cambrian radiation of brachiopods: A perspective from South China. Gondwana Research 14, 241-254.

Zuykov, M.A. \& Butts, S.H. 2008: Glyptorthis (Foerste, 1914) and Bassettella new genus (Brachiopoda: Orthida) from the Late Ordovician of the East Baltic. Journal of Paleontology 82, 197-200.

Figure Captions 
Fig. 1. $\square$ A-D. Novocrania anomala (Müller); NMW2009.15G.1, dorsal valve, Recent, Gullmaren Fiord, west coast of Sweden; $\square$ A, umbonal area showing a halo defining the boundary of the metamorphic shell (ms), note punctae (p) on the postmetamorphic shell; $\square \mathrm{B}$, surface of the postmetamorphic shell showing primary layer with a characteristic, radially arranged laths pattern; $\square \mathrm{C}$, D, transition from the metamorphic to postmetamorphic shell showing appearance of punctae, and radially arranged laths. $\square$ E, F, G, H, Orthisocrania curvicostae (Huene); NMW2009.15G.2, dorsal valve Upper Ordovician, Sandbian, Gryazno Formation, locality K-2, Klyasino Quarry, western St Petersburg region, Russia; $\square$ E, exterior; $\square$ F, oblique lateral view; $\square$ G, dorsal umbo showing boundaries of postmetamorphic (ms) and brephic shell (bs), note growth marks and radially arranged laths on the brephic shell suggesting that it was secreted by the adult mantle; $\square \mathrm{H}$, transition from the brephic to adult shell showing appearance of radial ornament.

Fig. 2. $\square$ A-I. Orthisocrania curvicostae (Huene), Upper Ordovician, Sandbian, Gryazno Formation, locality K-2, Klyasino Quarry, western St Petersburg region, Russia; $\square$ A, B, NMW2009.15G.3, dorsal valve interior, enlarged inner shell surface showing tubercles and punctae. $\square$ C, E, G, H, I, NMW2009.15G.4, ventral valve; $\square$ C, exterior; $\square$ E, ventral view of the umbonal area showing cicatrix attachment (ca); $\square$ G, enlarged transitional area from cicatrix to adult shell with distinct radially arranged laths pattern; $\square \mathrm{H}$, enlarged surface of cicatrix attachment showing initial attachment scar (ias); $\square$ I, oblique lateral view of ventral umbonal area. $\square$ D, NMW2009.15G.5, ventral valve, oblique posterior view showing uneven surface of a bioclast (as) used at initial attachment. $\square$ J, K, Craniops implicata (Sowerby), Silurian, Wenlock, Mulde Formation of Fröjel, Eksta b., Gotland, Sweden. $\square$ J, RM Br 24286a, ventral view of conjoined valves. $\square \mathrm{K}$, RM Br 24286b, dorsal exterior. 
Fig. 3. Craniops implicata (Sowerby), Silurian, Wenlock, Mulde Formation of Fröjel, Eksta b, Gotland, Sweden. $\square$ A, C, E-G, RM Br 24286c, ventral valve; $\square$ A, oblique posterior view showing initial attachment scar (ias) and outer boundary of cicatrix attachment (ca); $\square$ C, enlarged ventral umbonal area showing initial attachment scar; $\square \mathrm{E}$, oblique lateral view of ventral valve exterior; $\square$ F, oblique lateral view of initial attachment scar showing appearance radially arranged laths on the cicatrix surface. $\square$ B, D, I, RM Br 24286d, ventral valve; $\square$ B, cicatrix and initial attachment scar in the ventral umbo; $\square \mathrm{D}$, surface of the postmetamorphic shell showing primary layer with a characteristic, radially arranged laths pattern; $\square$ I, oblique lateral view of ventral umbonal area; $\square$ H, RM Br 24286e, dorsal valve, umbonal area showing boundaries of the metamorphic (ms) and brephic shell (bs). 
Fig 1

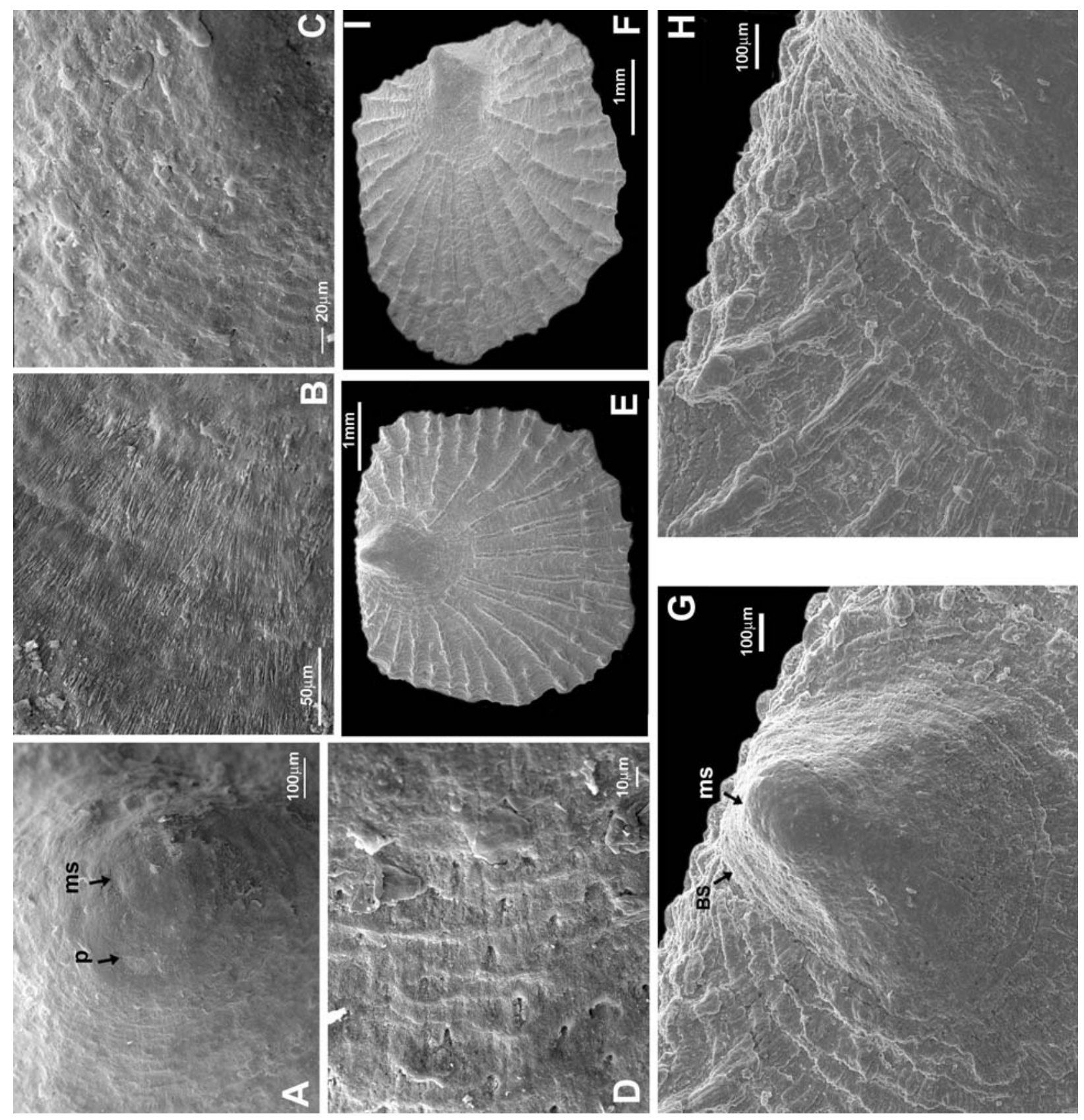


Fig 2
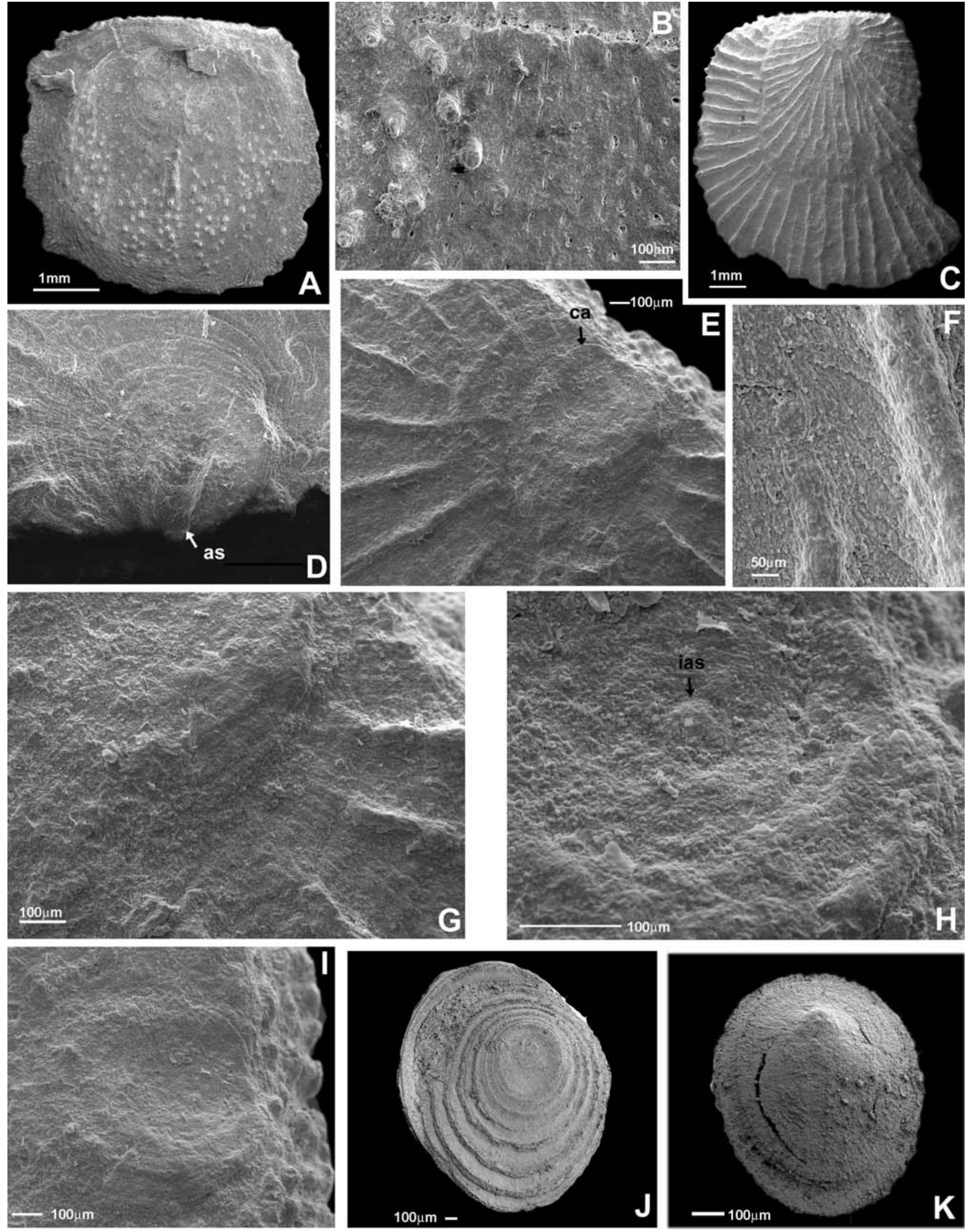

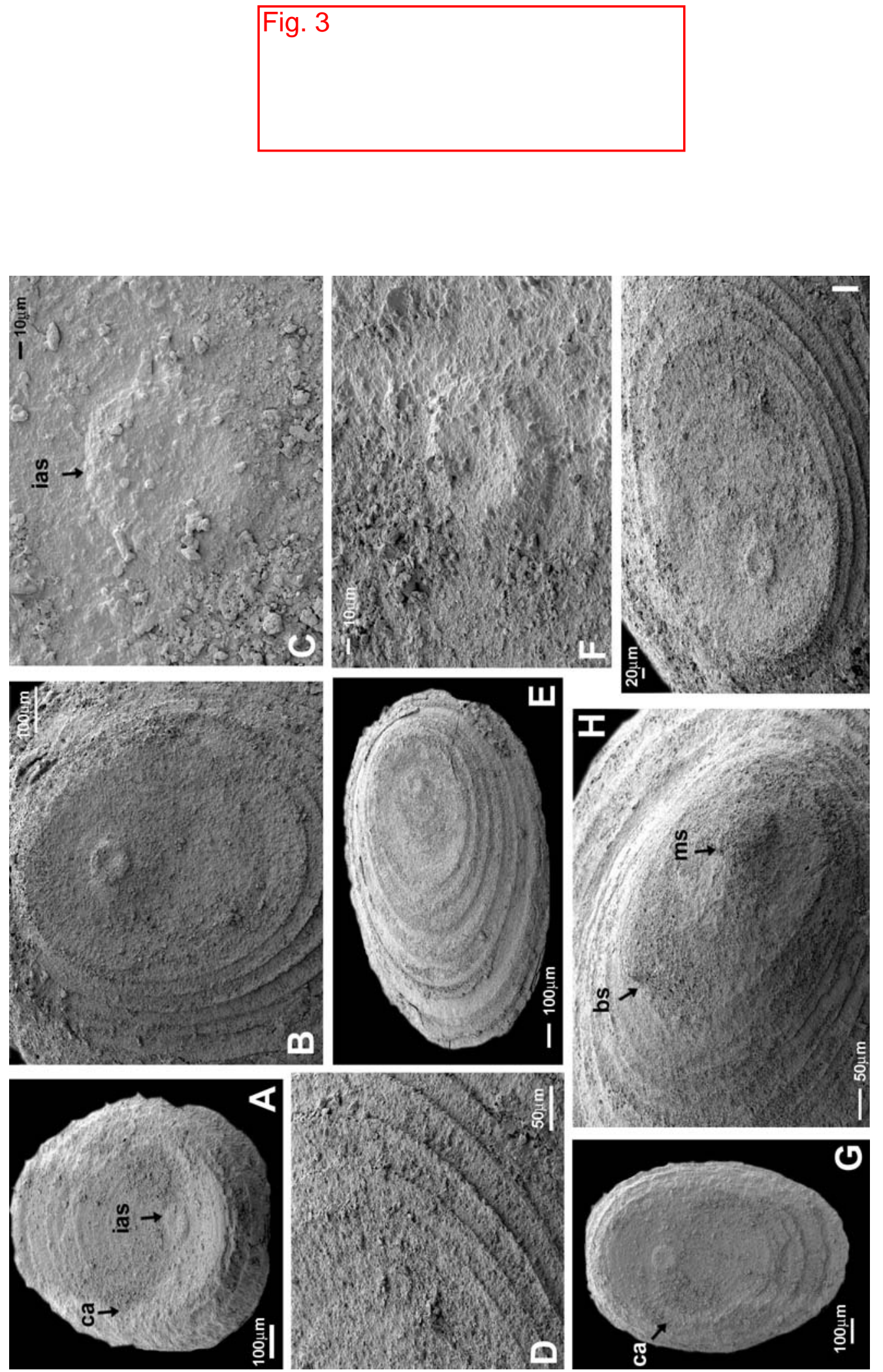